Kaygl, 31/2018: 404-430.

Araştırma Makalesi | Research Article

Makale Geliş | Received: 05.07.2018

Makale Kabul | Accepted: 20.09.2018

Yayın Tarihi | Publication Date: 30.10.2018

DOI: 10.20981/kaygi.480834

Aykut AYKUTALP

Dr. Öğr. Üyesi| Assist. Prof. Dr. Ağrı İbrahim Çeçen Üniversitesi, İ̈BF, Siyaset Bilimi ve Kamu Yönetimi Bölümü, Ağr1, TR Ağrı İbrahim Çeçen Univ., Faculty of E.A.S, Dep. of Political Sciences and Public Administration, Ağrı, TR

ORCID: 0000-0001-5991-0306 aaykutalp@agri.edu.tr

\author{
Adem ÇELİK \\ Dr. Öğr. Üyesi| Assist. Prof. Dr. \\ Kafkas Üniversitesi, İİBF, Siyaset Bilimi ve Kamu Yönetimi Bölümü, Kars, TR \\ Kafkas University, Faculty of E.A.S, Department of Political Sciences and Public Administration, Kars, TR \\ ORCID: 0000-0002-9297-1116 \\ ademcelik36@hotmail.com
}

\title{
Antonio Negri ve Michael Hardt Düşüncesinde İmparatorluk, Çokluk ve Biopolitik Üretim Kavramları Üzerine
}

$\ddot{\mathbf{O}} \mathbf{z}$

$\mathrm{Bu}$ çalışma son dönemin önemli düşünürlerinden Antonio Negri ve Michael Hardt'ın İmparatorluk, Çokluk ve Biopolitik üretim kavramlarına odaklanmaktadır. Çağdaş siyasal tartışmaların merkezindeki bu kavramlar yeni bir egemenlik biçimi olarak ele alınan İmparatorluk fikrinin düşünsel temellerini olduğu kadar çağdaş kapitalizmdeki ekonomik dönüşümü ve bu çağın yeni öznellik biçimini de tartışmaya açmaktadır. Negri ve Hardt'a göre İmparatorluk küresel uzamda işleyen bir ağ mantığı, egemenlik biçimi olarak ulus devletlerin siyasal sınırlarını aşan yeni bir egemenlik ve yönetimsel mantık olarak görülmektedir. Çokluk ise imparatorluğun iktidar ve komuta biçimlerine karşı kolektif ve müşterek bir toplumsal özne olarak ele alınmaktadır. Biopolitik üretim ise kapitalist üretimdeki maddi malların üretimini merkeze alan iş ve çalışma örgütlenmesini aşan duyguların, sembollerin, simgelerin, iletişimin ve işbirliğinin merkezinde olduğu hayatın üretimi olarak tarif edilmektedir. Bu üç kavram çağdaş dünyanın ekonomik, siyasal dönüşümünü anlamak açısından önemli bir çerçeve çizmektedir. Bu çalışma da üç kavramın sınırları dahilinde Negri ve Hardt düşüncesinin tartışmaya açtı̆̆ı küresel değişimlerin doğasını anlamayı hedeflemektedir.

Anahtar Kelimeler: İmparatorluk, Emperyal Egemenlik, Çokluk, Biopolitik Üretim, Maddi Olmayan Emek.

\section{On the Concepts of the Empire, Multitude And Biopolitical Production in the Thought of Antonio Negri And Michael Hardt}

\footnotetext{
Abstract

This study focuses on the ideas of Antonio Negri and Michael Hardt, the most influential thinkers of recent period, about the concepts of the Empire, Multitude and Biopolitical production. These concepts
} 
being at the center of contemporary political discussions problematise the ideaitonal foundations of the idea of Empire evaluated as a new form of sovereignty, the economic transformation in the contemporary capitalism and the new form of subjectivity in this age. To Negri and Hardt, Empire is seen as a logic of network operating at global level and a new logic of sovereignty and governance going beyond the political boundaries of nation states as form of sovereignty. In this regard, multitude is evaluated as a collective and joint social subject against the power and command forms of empire. As for biopolitical production, it is defined as the production of life in which feelings, symbols, communication and cooperation go beyond the understanding that centers the production of tangible goods within the capitalist production and work organization. These three concepts draw an important framework in terms of understanding the economic, political transformation of the contemporary world. In this study, it was aimed at interpreting the nature of global changes brought forward by the Negri and Hardt thought within the boundaries of these three concepts.

Keywords: The Empire, Imperial Sovereignty, Multitude, Biopolitical Production, Immaterial Labor.

\section{Giriş}

$\mathrm{Bu}$ çalışmanın konusu günümüzün önemli düşünürlerinden Antonio Negri ve Michael Hardt'ın kuramsal yaklaşımlarını tartışmaya açmaktır. Antonio Negri, İtalyan Otonomist hareketin en önemli kuramcilarından biri olarak 1960'lardan beri önemli tartışmaların gündeminde yer alan aktörlerden biridir. Michael Hardt ise Amerikan akademi dünyasında tanınan edebiyatçı ve İtalyan Otonomist hareketin metinlerinin İngilizce konuşulan dünyada tanınmasını sağlayan önemli bir entelektüeldir. Otonomist hareket temelde "proletaryayı, kendi çıkarlarına sahip özerk bir öznellik olarak hem pratikte hem de kuramsal düzeyde yeniden kurmayı" hedefleyen politik bir harekettir (May 2000: 49). Otonomist hareket toplumsal değişimi yukarıdan, hiyerarşik bir biçimde örgütlenmişs siyasal organizasyonların bir sonucu olarak değil, işçiler, kadınlar, öğrenciler gibi farklı toplumsal öznelerin aşă̆ıdan örgütlendiği, ortak hareket edebilme olanaklarının geliştiği politik hareketin yaratılması olarak görmektedir. Bu bakımdan otonomist hareket, 1970'lerde kentsel toplumsal hareketler olarak tarif edilen kadın, çevre vb. hareketler ile önemli benzerlikler göstermektedir (Castells 2015). Otonomistler, sermaye, iş ve toplumsal kimlikler gibi farklı alanlarda sermaye tarafından kuşatılan bütün toplumsal yapıların eleştirisini içeren bir ret stratejisi benimsemişlerdir. Otonomistlere göre sermayenin gelişim dinamikleri işçi sınıfı 
mücadeleleri tarafından belirlenmektedir. $\mathrm{Bu}$ açıdan işçi sınıfına otonom bir öznellik atfeder. Bu bir bakıma Foucault'nun direniş iktidarı belirler yaklaşımını içermektedir. Diğer taraftan iktidar da, direniş pratiklerini ve söylemlerini ele geçirmeye çalışan bir makinedir. Negri ve Hardt'in metinlerinde, otonomist hareketin ret stratejisi, direniş ve iktidara ilişkin çözümlemelerinin izlerini görmek mümkündür.

Antonio Negri ve Michael Hardt'ın 1999 yılında çıkan Imparatorluk kitabı Sovyetler Birliği’nin çöküşü ve örgütlü kapitalizmin değişimiyle birlikte ortaya çıkan yeni küresel düzenin kavranmasına ve yeni sol siyasete kuramsal katkıya yönelik bir çalışmadır. Kitap basıldığı dönemde akademik dünyada ilgiyle karşılanmış, Frederic Jameson tarafından "yeni milenyumun ilk büyük teorik sentezi” ve Slavoj Zizek tarafından "yeniçağın komünist manifestosu" olarak tarif edilmiştir. İmparatorluk çalışmasının ilgi odağını ulus devlet egemenliğindeki gerileme, emperyalizmin sonu ve biopolitik üretim gibi çağdaş dünyadaki değişimler oluşturmaktadır. İmparatorluk kavramı ile dünya kapitalizminin küresel ölçekte tek bir egemen hükmetme mantığı tarafından biçimlendirildiği savunulmaktadır. İmparatorluk tartışması, modern egemenliğin doğasına içkin dikotomik ayrımların, içerisi ve dışarısı arasındaki bölünmelerin sonuna işaret eden emperyal egemenlik olarak tarif edilen yeni bir egemenlik paradigmasını merkeze almaktadır. İmparatorluk bir yönüyle, Otonomist hareketin 1970'lerden beri tartıştığı kavramların çağdaş yeniden yorumlanması, diğer yönüyle de Foucault, Deleuze ve Guattari gibi Fransız düşüncesinin önemli temsilcilerinin teorik yaklaşımlarını çağdaş kapitalizmi, küresel yönetsel aygıtları ve öznellik oluşumlarını tanımlamada merkeze alan yeni bir sentez olarak görülebilir.

İmparatorluk tartışmalarının devamı niteliğinde görülebilecek olan Çokluk: Imparatorluk Çă̆ında Savaş ve Demokrasi kitabı, daha önceki metinlerde çerçevesi çizilen ve yeni dönemin öznesi olarak görülen Çokluk'u ayrıntılı bir biçimde ele almaktadır (Hardt ve Negri 2004). Negri ve Hardt'a göre İmparatorluğun ortaya çıkış1 aynı zamanda karşı-iktidar olarak çokluğun ortaya çıkışına da gönderme yapar. Çokluk, tek bir özne figürünü merkeze almayan, farklı toplumsal sınıfların, kimliklerin, hareketlerin demokratik birliği olarak görülmektedir. Çokluk tarihe müdahale edecek 
özne olarak tarif edilmektedir. Çokluk tartışması 1990'lardan beri radikal demokrasi kuramcılarının gündeme getirdiği işçi sınıfı siyasetinin merkeziliğinin sonu fikrini paylaşmaktadır. Radikal demokrasinin önemli temsilcilerinden Ernesto Laclau ve Chantal Mouffe'un çalışmaları işçi sınıfını tarihin yapıcısı olarak gören Ortodoks Marxist kuramsal yaklaşımların eleştirisini içermektedir(Laclau ve Mouffe, 2008). Laclau ve Mouffe'a göre ekonomik kategorilerle tanımlanan ve tüm toplumsal farklılıkları ortadan kaldıran işçi sınıfı kavramı yerine, farkı kimlikleri, sınıf kategorilerini, çevre ve kadın hareketlerini de içeren karşı-hegemonya kurucu bir özne olarak halk kavramı kullanılmalıdır (Laclau 2007: 248-249). Halk, yeni dönemin öznesi olarak görülmektedir. Laclau ve Mouffe'un halk tartışmasına benzer bir biçimde, çokluk da yeni dönemin özne arayışına farklı bir yanıt olarak görülebilir. Diğer bir ifade ile çokluk, emperyal egemenliğe ve kapitalist rasyonelliğe karşı yeni siyasetin öznesidir. Özne tartışması, yeni sol siyasetin 1990'lardan beri içine kapanmasına neden olan reel sosyalizm deneyimi sonrası birçok farklı ülkeden aktivistler arasında tartışılan önemli bir gündem maddesi haline gelmiştir. Özellikle Arap Baharı, "Wall Street'i İşgal Et" hareketleri gibi kentsel hareketler bu tartışmaların bir sonucu olarak görülebilir. Negri ve Hardt'a göre bu hareketler Çokluk'un demokratik yapısını ve yatay örgütlenme pratiklerini inşa eden ve kurumsal siyasetin reddini talep eden siyasal örgütlenmeler dizisi olarak görülmelidir (Hardt ve Negri, 2012). Başka bir değişle bu hareketler özerk, katılımcı ve temsilin reddini içeren bir siyasetin biçimin doğuşu olarak yorumlanmalıdır. Negri ve Hardt'ın metinlerinin merkezini, modern egemenlikten emperyal egemenliğe, ulus-devletler düzeninden imparatorluğa, işçi sınıfından çokluğa, disiplin toplumundan denetim toplumuna geçiş yaşandığı fikri oluşturmaktadır. $\mathrm{Bu}$ çalışma geçiş fikrinin merkezini oluşturan İmparatorluk, Çokluk ve Biopolitik üretim kavramlarını ele almaktadır.

\section{İmparatorluk: Küresel Düzenin Olușumu}

Antonio Negri ve Michael Hardt'1n Imparatorluk adlı eseri, yeni bir küresel düzenin kuruluşunu tartışmaktadır. Bu küresel düzen modern egemenlikten emperyal 
egemenliğe, kapitalist üretimdeki bir dizi dönüşümden ve çokluk’un yeni bir öznellik biçimi olarak ortaya çıkışına kadar farklı toplumsal süreçleri kapsamaktadır. İmparatorluk, “iletişim ağlarından oluşan ve insan, para ve fikirlerin küresel bir akış içerisinde olduğu yenidünyada, politik gücün doğasının radikal” bir değişimini simgelemekte ve toplumsal, siyasal değişimin izlerini sürmeyi hedeflemektedir (Gilbert 2012: 227). İmparatorluk ile birlikte ulus devletlerin üzerinde yükseldiği modern egemenlik ve emperyalist uygulamalar yerini egemenliğin küresel ölçekte yayıldı̆̆g, endüstriyel üretimin yerini biopolitik üretime, emperyalizmin yerini emperyal egemenliğe bıraktığı görülmektedir (Negri 2005a: 19). Küresel ölçekte piyasa ekonomisin genişlemesi, iletişim ve ulaşım olanaklarının artışı, BM, Dünya Bankası, IMF ve küresel sivil toplum örgütlerinin etkinliğindeki artış yeni bir egemenlik paradigması ortaya çıkarmaktadır (Hardt ve Negri 2003a: 17). Bu yönüyle iktidarın belirli bir devletin ve kurumun otoritesi altında işlemediği yeni bir tarihsel döneme girilmektedir. $\mathrm{Bu}$ değişimlere paralel olarak iktidar merkezsizleşmektedir ve imparatorluk bu merkezsiz mimaride bir dizi süreç sonucunda oluşmaktadır (Negri 2005a: 11). Bu süreçlerden ilki küreselleşme, ikincisi ulus devlet egemenliğindeki azalma, üçüncüsü biopolitik üretimdir. İmparatorluk küresel ölçekte hakim olan tüm yönetim biçimlerini kapsayan karma bir niteliğe sahiptir ve Dünya Bankası, IMF, Ulusal Devletler ve yerel otoriteleri içermektedir. İmparatorluk, sınırların anlamını yitirdiği yeni bir merkezsiz yönetim biçimi olarak küresel dünyamızı biçimlendiren aygittır (Hardt ve Negri 2003a: 17).

İmparatorluğun oluşumunun en önemli göstergelinden biri Roma imparatorluğunda da hakim olan emperyal hak kavramının yeniden ortaya çıkmış olmasıdır. Emperyal hak kavramı, etik ile tüzelin evrensel birlikteliği olarak görülmektedir. Roma imparatorluğu egemenlik kurduğu bölgeler ve kıtaları evrensel barışın mekanı olarak sunmaktadır (Hardt ve Negri 2003a: 35). Modern egemenlik, ulus devlet ve küresel hak nosyonu ile ulus devletler arasında hakim olması istenen barış fikrinin çelişkili birlikteliği yoluyla bu iki hak nosyonunu bir birinden ayırmıştır. İmparatorluğun kuruluşu hem uluslararası hak nosyonunu hem de küresel barışı olanaklı 
kılmaya aday bir egemenlik fikri ortaya çıkarmıştır. Negri ve Hardt bu süreci, "haklı savaş” kavramının yeniden diriltilmesi olarak ele almaktadır. Haklı savaş kavramı, "bir devlet toprak bütünlüğünü ve politik bağımsızlığını tehlikeye sokan bir saldırı tehdidiyle yüz yüze kaldığında jus ad bellum hakkına (savaş yapma hakkına) sahiptir” ilkesi üzerine kuruludur (Hardt ve Negri 2003a: 36). Haklı savaş doktrini, savaşın politik bir araç olarak görülmesini sağlarken aynı zamanda savaşın etik yoluyla meşrulaştırılmasıdır. Bu yönüyle İmparatorluk esnek ve yatay ilişkiler üzerinden işleyen yeni bir iktidar mimarisi oluşturmaktadır (Hardt ve Negri 2003a: 37). İmparatorluk "kendi başına güç temelinde değil, gücü hakkın ve barışın hizmetinde gösterme kapasitesi temelinde oluşur" (Hardt ve Negri 2003a: 39). Negri ve Hardt'ın da belirttiği gibi:

[B]u dönüşümün belki de en önemli belirtisi müdahele hakkı denen bir hakkın gelişmesidir. Bu genelde dünya düzeninin hakim öznelerinin insani sorunları engelleme ya da çözme, anlaşmaları güvence altına alma ve barışı dayatma amacıyla öteki öznelerin topraklarına müdahale etme hakkı ya da görevi olarak anlaşı1ır. Müdahale hakkı uluslararası düzeni korumak için Sözleşmeyle Birleşmiş Milletler'in eline verilen araçlar takımı arasında göze en çok çarpan haktır, ama bu hakkın günümüzdeki düzenlenişi niteliksel bir sıçrama anlamına gelir. Artık eski uluslararası düzende olduğu gibi tek tek egemen devletler ya da ulus-üstü güç $(\mathrm{BM})$ sadece gönüllü olarak imzalanmış uluslararası anlaşmaların uygulanmasını ya da dayatılmasını sağlamak üzere müdahalede bulunmuyor. Şimdi ister hak isterse konsensüs yoluyla meşruluk kazanmış ulus-üstü özneler herhangi bir türden acil durum ve üstün etik ilkeler adına müdahalede bulunuyor. $\mathrm{Bu}$ müdahalenin arkasında, salt kendi başına bir sürekli acil ve istisnai durum değil; temel adalet değerlerine müracaatla haklılaştırılan bir sürekli acil ve istisnai durum yatıyor. (Hardt ve Negri 2003a: 42).

İmparatorluğun kuruluşuna etki eden önemli bir süreçte ulus devlet egemenliğinde oluşan gerilemedir. Ulus devlet örgütlenmesi, küresel ölçekte emek, sermaye, simge, sembol, iletişim ve enformasyonun dolaşımındaki hızlanma nedeniyle zaman-mekan üzerindeki denetim ve kontrol olanaklarını kaybetmektedir (Negri 2005a: 31). Ulus devletler modern egemenlik mantığının hakim olduğu önemli bir mekan olarak, egemenliğin otonom biçimde ayrıldığı, dışarı ve içerisi arasında belirli sınırılar çizildiği örgütlenme biçimidir (Hardt ve Negri 2003a: 18). Ulus devletler Westphalia'dan bu yana belirli bir toprak parçası üzerinde meşru güç kullanma tekeli olarak 
tanımlanmaktaydı (Weber 1993: 80). Buna karşın yeni oluşmakta olan egemenlik paradigması toprak temelli değildir. $\mathrm{Bu}$ yönüyle imparatorluk merkezsiz oluşuyla tanımlanmaktadır. Bu çözümleme, Foucault'un iktidarın her yerdeliği çözümlemesine benzemektedir. Foucault'a göre "iktidar her yerde hazır ve nazırdır: ama bu, her şeyi yenilemez birliğinin çatısı altında kümeleştirme ayrıcalığına sahip olmasından değil, her an, her noktada, daha doğrusu bir noktayla bir başka nokta arasındaki her bağıntıda ürüyor olmasından kaynaklanır. İktidar her yerdedir; her şeyi kapsadığından değil, her yerden geldiğinden dolayı her yerdedir" (2010: 72).

İmparatorluğu merkezsiz, hiyerarşisiz, topraksız bir tanımlama girişimi bir bakıma ulus-devlet merkezli emperyalizm çözümlemelerini tartışmaya açmak anlamına gelmektedir. Negri ve Hardt'a göre (2003a: 18) emperyalizm kavramı "Avrupalı devletlerin egemenliklerini kendi sınırlarının ötesine" taşıma girişimidir. $\mathrm{Bu}$ açıdan modern egemenlik sadece Avrupa merkezli bir okumayla anlaşılamaz. Kolonilerdeki yönetim tekniklerinin etkisiyle yenilenen ve dönüşen bir içeriğe sahiptir. Emperyalizm, genel olarak kapitalizmin yönetme ve sömürme mantığı olarak sermaye birikim süreçleriyle ilgili bir kavram olarak kullanılmıştır (Luxemburg, 2004). Bu yaklaşımda dünya kapitalist ekonomisi merkez ve çevre ülkeler olarak ele alınmaktadır. Kapitalizm çevre ülkelerdeki zenginliğin merkez ülkelere aktarıldığı bir işleyişe sahiptir. Kapitalizm bu yönüyle gücün ve zenginliğin merkez ülkelerde yoğunlaştığı bir ekonomik sistem olarak varlığını dışarıdaki kaynakların sömürüsü yoluyla sürdürebilmektedir. Bu yaklaşım teorik olarak, kapitalizmin ve emperyalizmin değer aktarımı yoluyla genişleyen mantığının ortadan kalkmasıyla birlikte çökeceğini iddia etmektedir. Hardt ve Negri’nin de belirttiği gibi “Marxist düşünce geleneğinin emperyalizm üzerine geliştirdiği merkezi argümanlardan biri, kapitalizmle yayılma arasında içkin bir ilişkinin olduğu ve kapitalist yayılmanın kaçınılmaz olarak emperyalizmle politik biçim aldığı yolundadır" (Hardt ve Negri 2003a: 236). İmparatorluk yönündeki gelişmeler, emperyalizm kuramının entelektüel ve maddi temelini ortadan kaldırmıştır. Modern egemenliğin bir parçası olan emperyalizme dayalı yönetim teknikleri yerini imparatorluğa bırakmıştır. 
İmparatorluğa geçişi haritalandırmamıza olanak sağlayan üç tarihsel gelişme vardır. Birincisi, kolonilerin özgürleşmesi, ikincisi, üretim sürecinin merkezsizleşmesi ve üçüncüsü ise disipline dayalı üretim biçiminin ve disiplin toplumunun küresel yayılımını olanaklı kılan uluslararası düzenin oluşumudur (Hardt ve Negri 2003a: 259). İlk olarak sömürgelerin özgürleşmesi süreci, ABD ve Sovyetler Birliği arasında yaşanan Soğuk Savaş dönemine denk gelmiştir. Soğuk savaşın aktörü olan bu iki devletten biri tarafında yer almak koloniler özgürleşme sürecini geciktirmiştir. Avrupa devletleri tarafından 19. ve 20. yüzyılda sömürgeleştirilen toplumlar, yeni küresel düzen içerisinde özgürlüklerine kavuşmuşlardır. Bu özgürleşme daha çok askeri zor aygıtları üzerinden egemenlik kuran Avrupa sömürgeci geleneğinden farklı olarak, ekonomik kategorilerin merkeze geldiği yeni bir aşamaya gönderme yapmaktadır. $\mathrm{Bu}$ aşama sömürgeci pratiklerinin sonuna ve dolayısıyla imparatorluğun oluşumuna örnek gösterilmektedir (Hardt ve Negri 2003a: 261). İkinci olarak, kapitalist üretimde yaşanan merkezsizleşmedir. Ulusal ekonomiler, ulusüstü şirketlerin ekonomik süreçler ve finansal ağlar üzerindeki belirleyiciliği nedeniyle önemlerini yitirmektedir. Ulusüstü korporasyonların etkinliğindeki artış çevre ülkelerdeki teknolojik alt yapıyı ve üretim ilişkilerini olduğu gibi, emek piyasalarını da dönüştürerek sermayenin akışkanlığını olanaklı kılacak zemini hazırladı. İmparatorluğun oluşumu ulus-devletlerin sınırları dahilinde işleyen sermaye birikim süreçlerinin küresel uzamda genişlemesine olanak sağladı (Hardt ve Negri 2003a: 262). Üçüncü olarak, disiplinci üretim mantığı ve disiplin toplumunun kurumlarının küresel yayılımı imparatorluğun oluşumunu gösteren önemli bir eğilimdir. Fordist ücret rejimi, Taylorist emek örgütlenmesi, modernleşmeyi ve kalkınmayı hedefleyen refah devletinin gelişmekte olan ülkelerde ortaya çıkmasına neden olmuştur. Gelişmekte olan bu ülkeler küresel ekonomik ağlara ancak merkez ülkelerde üretilen disiplinci kurumların kendi ülkelerinde de yerleşmesi yoluyla dahil olmuşlardır. Devlet eliyle sanayileşmeyi merkeze alan politikalar ve ithal ikamesine dayalı ekonomik kalkınma reçeteleri üretim süreçlerini şekillendiren disiplin rejiminin küresel ölçekte yaygınlaşmasını beraberinde getirdi. Emperyalizm, sanayileşme ve kalkınma yönündeki modernleşmeci pratiklerin etkinliğindeki azalmanın sonucunda ortaya çıkan değişimle birlikte hakimiyetini yitirmeye başlamıştır (Hardt ve Negri 
2003a: 262-263). Sonuç olarak toplumsal, ekonomik değişim dinamikleri en nihayetinde imparatorluğun oluşumu yönünde bir eğilimin ortaya çıkmasına olanak sağlayacak maddi koşulları hazırlamıştır.

İmparatorluğun kuruluşunun diğer bir göstergesi kapitalist üretim biçiminde ortaya çıkan dönüşüm ve piyasasının ekonomisinin küresel ölçekte genişlemesidir. Bu dönüşüm en belirgin göstergesi, modernite özgü ekonomik alan-siyasal alan, içerisidışarısı ve üretim alanı-yeniden üretim alanı arasındaki keskin ayrımların bulanıklaşmasıdır. Modern fabrika rejimi, sanayi öncesi toplumlarda sıkça görülen üretim mekanı ile yaşam mekanı arasındaki örtüşmeyi değiştirmiştir. Üretimin mekansal farklılaşması süreci ekonomi ve siyaset ayrımının temelini oluşturmaktadır. Ulus devlet örgütlenmesi ve sanayi üretiminin örgütlenmesi arasında kurulmak istenen analoji günümüzde ortaya çıkmakta olan küresel imparatorluk oluşumunu açıklayamamaktadır. Çağdaş dünyada üretim sadece maddi nesnelerin üretimi olmaktan daha çok hayatın üretimi olarak biopolitik hale gelmektedir. Biopolitik üretim, hizmet üretiminin yaygınlaştırarak farklı coğrafyalardaki emek, meta, sermaye, iletişim ve işbirliği ağlarını ortak paydada birleştirmektedir. Üretimin hayatın üretimi haline gelmesi, ekonomi ve ekonomi dışı alanlar olarak ayrıştırılan mekansal bölünmeleri ortadan kaldırmıştır. İmparatorluk da, üretimin doğasında yaşanan tarihsel dönüşüme verilen bir cevaptır. Piyasa toplumu ancak piyasanın işleyişini sağlayan dışsal müdahaleyle varlığını sürdürebilir (Polanyi 2006). İmparatorluk bu bakımdan küresel piyasa toplumun işleyişini olanaklı kılan dışsal bir güç veya yeni bir iktidar mantığg olarak çağdaş kapitalizmin yayılmasını olanaklı kılan egemen güçtür. Başka bir değişle imparatorluk dünya piyasanın denetimini hedefleyen komuta ve kontrol tekniklerinin yayılışını sağlayan hukuki ve politik bir egemenlik anlayışıdır.

\section{Egemenliğin Yeni Biçimi: Modern Egemenlikten Emperyal Egemenliğe Geçiş}

İmparatorluğun oluşumuyla birlikte ulus devletlerin egemen birimler olarak sınırları üzerindeki denetim ve kontrol olanaklarını yitirmesi, sömürgeciliğin çöküşü ve 
ulusüstü kurumların oluşumu modern egemenlikten emperyal egemenliğe doğru tarihsel geçişi sembolize etmektedir. Negri ve Hardt'a göre (2003a: 156) postkolonyal ve postmodern çalışmalar modern egemenlikten emperyal egemenliğe doğru yaşanan dönüşümü anlamamıza olanak sağlayan bir literatür ortaya çıkardıkları gibi bu dönüşümü anlamamızı sağlayan çözümleyici araçları da sunmaktadırlar. Postmodern ve postkolonyal çalışmalar modern egemenliğin doğasında var olan ikili karşıtlıklar üzerinden tanımladığı biz-onlar, ben-öteki, siyah-beyaz, içerisi-dışarısı, yerel-evrensel gibi dikotomik ayrımları sömürgeci anlayışın ve ırkçılık düşüncesinin bir uzantısı olarak eleştiri konusu haline getirmiştir. Bu eleştirel tutum bir yönüyle modern egemenliğin politik dünyasına ve iktidar tekniklerine yönelik yıkıcı bir etkiye sahiptir. Negri ve Hardt'ın tarif ettiği gibi postmodern ve postkolonyal yaklaşımlar modern egemenliğin özcü ve manici tanımlama biçimlerine karşı farklılık, melezlik, yataylık gibi özgürlüğü merkeze alan politikaların oluşturulmasında ortaklaşmaktadırlar (Hardt ve Negri 2003a: 164).

Negri ve Hardt'a göre postmodernler, farklılığı, akışkanlığı ve melezliği merkeze koyarak modernitenin ürettiği kültürel, rrksal ve cinsel olarak tek boyutlu toplum okumasını ve onun ürettiği iktidar ilişkilerini yapısöküme uğratmışlardır. Kültürel, 1rksal ve cinsiyete dayalı manici ayrımlarının eleştirisi beraberinde modern egemenliğin üzerine bina edildiği mekan olarak ulus devletin yarattığı bölünmeleri tartışmaya açmaktadır. Farklılık, melezlik, akışkanlık ve yersiz-yurtsuzlaşma kavramları modern egemenliğin doğasındaki hiyerarşilere karşıt bir söylem olarak kurulmuştur. Negri ve Hardt'a göre (2003a: 158) modernliğe yönelik bu yönlü bir eleştiri, eski egemenlik mantığını dışlamakla birlikte yeni oluşmakta olanı ise içermek gibi bir sorunla karşı karşıyadır. Başka bir ifadeyle postmodernlerin radikal aydınlanma eleştirisi, iktidar ve tahakkümün doğasını açığa çıkarma konusunda ne denli başarılı ise, küreselleşme çağında farklılık, melezlik ve yerellik üzerine kurulu emperyal egemenlik mantığına eleştirel yaklaşım konusunda o denli başarısızdır (Hardt ve Negri 2003a: 157).

Negri ve Hardt'a göre modern egemenlikten emperyal egemenliğe doğru yaşanan değişimler küresel dünyamızı biçimlendiren yeni bir egemenlik mantığı ortaya 
çıkarmıştır. Yeni egemenlik mantığı küresel kontrol ve komuta teknikleri uyarınca çokluğun üretken enerjisini denetim altına alacak bir yönetme biçimidir (Foucault 2006: 308-309). ${ }^{1}$ Modern dönemde okul, hapishane, kilise, fabrika gibi disiplinci mekanlar üzerinden öznenin inşası hedeflenirken, emperyal egemenlik çağında disiplinden daha çok denetim hedeflenmektedir. Bu açıdan modern egemenlik öznelliği mekan dolayımı ile üreten bir bio-iktidarken, emperyal egemenlik, öznellik üretimini toplumsal ilişkilerin geneline yayan ve yaşamın üretimi ve yeniden üretimini hedefleyen genelleşmiş bio-iktidardır. Emperyal egemenlik, (I) manici bölünmelerin ortadan kalkması, (II) emperyal ırkçılığın hakim olması ve (III) öznelliğin yeniden üretimi biçiminde kendisini göstermektedir.

(I) Emperyal egemenlikle birlikte içerisi ve dışarısı arasındaki ayrım olanaksızlaşmıştır. $\mathrm{Bu}$ bakımdan emperyal egemenlik, mekanın içi ve mekansal sınırların dışı gibi dikotomik ayrımlar üzerine kurulu olan modern egemenliğin sonuna gelindiğini göstermektedir. Modernlik üzerine çalışan düşünürlerin büyük çoğunluğu toplumsal hayatı karşıtlıklar üzerinden tarif etmiştir (Frisby, 2012: 25). ${ }^{2}$ Negri ve Hardt'ın da örnek verdiği gibi içerisi ve dışarı nosyonu Machiavelli, Spinoza, Kant, Marx ve Foucault gibi düşünler tarafından farklı saiklerle dile getirilmiştir (Hardt ve Negri, 2003a: 198). Örneğin Marx komünizmi kapitalist toplumun bağrından çıkacak ortak mülkiyet anlayışına dayalı bir dışarısı nosyonu üzerinden tarif eder. Anarşist düşünürler devleti, insanın doğuştan iyi olan doğasını bozan ve var olan kötülüklerin kaynağı olan örgütlenme olarak tanımlarken, bir bakıma devletin içindeki kötü insan doğası ve devletin dışındaki iyi insan doğası kavrayışıyla modernliğe ait içerisi-dışarısı dikotomisini yeniden üretirler (Newman 2006: 27-28). Negri ve Hardt’a göre (2003a: 201) modern egemenliğe içkin olan içerisi-dışarısı anlayışı emperyal egemenlikle

\footnotetext{
${ }^{1}$ Foucault benzer bir biçimde marjlarda kurulu olan ve tamamen olumsuz işleveler sahip kapalı kurumların amacının kötülüğü durdurmak, iletişimleri kopartmak ve zamanı askıya almak biçimindeki disiplinci mantığı abluka disiplin olarak formüle etmektedir. Zararlı birlikleri engellemek üzerine kurulu abluka disiplin yerini süreç içerisinde yararlı birlikler oluşturmayı hedefleyen mekanizma disipline bırakmıştır. Bkz. (Foucault 2006: 308-309).

${ }^{2}$ Modernliğin ne olduğu sorusu sosyoloji disiplininin kurucuları tarafından dikotomiler üzerinden yanıtlanmıştır. Ferdinand Tönnies'in Gemeinschaft (cemaat) ve Gesellschaft (toplum), Emil Durkheim'in mekanik dayanışmaya dayalı toplumlar ile organik dayanışmaya dayalı toplumlar, George Simmel'in paraya dayalı olmayan ekonomiler ile paraya dayalı ekonomiler arasında kurdukları dikotomiler buna örnek gösterilebilir. Bkz. (Frisby 2012: 25).
} 
birlikte ortadan kalkmaktadır. Bu dönüşüm bir bakıma merkez ülkeler ve çevre ülkeler ayrımı üzerinde inşa edilen emperyalizm teorilerinin de sonuna işaret ettiği gibi ulus devletin içi ve dışı anlayışını da ortadan kaldırmaktadır. Bu yönüyle yeni doğmakta olan egemenlik biçimi dışarısı nosyonunu reddeden bir mantıkla işlemektedir (Lemke 2013: 92).

(II) Kolonyal yönetimlerin meşrulaştırılmasında merkezi bir yere sahip olan 1rkçılık düşüncesi ortadan kalkmakta ve 1rkçılık biçim değiştirmektedir. İnsan toplumlarını biyolojik ve genetik özellikleri üzerinden sınıflayan ve hiyerarşiler inşa eden modern ırkçılık anlayışı yerini, farklılık, melezlik gibi kültürel kategorileri ön plana çıkaran emperyal ırkçılığa bırakmaktadır. Yeni dönemde ırkçılık biyolojik kategoriler üzerinden değil, kültürel değerler üzerinden üretilmektedir. Diğer bir ifade ile biyolojik bir kategori olarak 1rk düşüncesi terk edilmiş ama kültür, biyolojik 1rkçılığın terk edilmesinin yarattığı boşluğu doldurmuştur. Emperyal 1rkçılık, ırka dayanmayan, ırksız bir ırkçılıktır ve kültürel kategoriler üzerinden üretilmektedir. Emperyal 1rkçılık, kültürlerin esneklik ve bağdaşırlığına katı sınırlar koyarak, kültürlerin karışmasına izin vermenin nafile hatta tehlikeli olduğunu savunur (Hardt ve Negri 2003a: 207). Bu anlamıyla emperyal 1rkçılık bir hiyerarşi değil bir ayrım projesidir ve kültürler arasında aşılamaz ayrımlar olduğu düşüncesi üzerine kuruludur. Emperyal ırkçılık farklılıkları yok saymayan ama onların farklılıklarını bir dışlama unsuru olarak gören yeni bir mantık sunmaktadır. Postmodern ve postkolonyal teori emperyal egemenlikle birlikte ortadan kalkmakta olan biyolojik ırkçılığın eleştirisi ve modern 1rkçılığa karşı kültürel farklılığın teorisi olarak okunabilir. Emperyal 1rkçılık, modern ırkçılıktan farklı olarak postmodern teorinin vurgulamaktan hoşlandığı kültürel kategoriler üzerinden yeniden üretilmektedir. Bu bakımdan postmodern ve postkolonyal teorinin eleştirdiği 1rkçılık düşüncesi hali hazırda varlığını sürdürmektedir. İmparatorluğun mantığı uyarınca kültürel ayrımlar üzerinden yeni bir biçim almıştır. Bu yeni biçim, siyah-beyaz gibi biyolojik hiyerarşiler üzerinden değil, Sırplar ve Hırvatlar, Hutular ve Tutsiler, Afro-Amerikanlar ve Koreli-Amerikanlar ayrımı üzerinden şekillenmektedir (Hardt ve Negri 2003a: 207). Emperyal 1rkçılık, kültürel farklılıklar 
oyununa ve sürekli olarak genişleyen alanı içindeki mikro çatışmaların idaresine dayanır (Hardt ve Negri 2003a: 209). Bu yönüyle “emperyal 1rkçılık ya da farklılık temelli ırkçılık ötekileri kendi sınırları içine alır ve sonra bu farklılıkları bir kontrol sistemi içinde yönetir" (Hardt ve Negri 2003a: 209).

(III) Emperyal egemenlik, öznelliğin üretiminin mekansal ayrımlarının bulanıklaşmasıyla tarif edilmektedir. Modernliğin içerisi ve dışarısı ayrımı üzerine kurulan manici mantığı öznellik üretiminde de kendisini göstermektedir. Modern toplum, öznelliğin üretildiği farklı kompartımanlardan oluşan bir takım ada olarak görülebilir. Bu kompartımanların her biri öznelliğin üretildiği özel bir yer veya mekanla ilişkilidir. Her yerin veya mekanın öznelik kuralları ve mantığı bir birinden farklıdır. Örneğin okul bize sadece orada olduğumuzu değil aynı zamanda evde veya fabrikada olmadığımızı hatırlatacak sembollerle donatılmıştır. Bu semboller içerisi olarak okulun öznellik üretimini dışındaki kurumlardan farklı olduğunu gösterir ve kendisini dışardan ayıran sınırların korunmasını hedefler. Negri ve Hardt'ın da vurguladığı gibi "modern toplumsal teori tedrici bir biçimde her tür toplum-öncesi öznellik nosyonunun içini boşaltır ve öznelliğin üretimini hapishane, aile, fabrika ve okul gibi belli başlı toplumsal kurumlarının işleyiş mekanizmalarına yerleştirir” (Hardt ve Negri 2003a: 209). Bu yönüyle modernlik hem öznelliğin üretildiği hem de disiplin altına alındığı mekanların genişlemesiyle tarif edilebilir (Foucault 2010: 103). Bu anlamiyla "her kurumun sınırları içinde birey en azından kısmen öteki kurumların kuvvetlerine karşı korunur; cemaat içinde normal olarak aile kuralları geçmez, evde de normal olarak fabrika disiplini işlemez. Sınırları açıkça belli kurumsal yer, üretilen öznelliklerin düzenli ve sabit biçimine yansır" (Hardt ve Negri 2003a: 210).

İmparatorluk bir yönüyle mekan dolayımıyla öznellik üretiminin krizi olarak okunabilir. $\mathrm{Bu}$ sözü geçen kurumların artık öznellik üretmediği anlamına gelmemektedir. Ancak emperyal egemenlikle birlikte, kurumların sınırlı uzamını belirlemek için kullandığı çitler yıkılmaktadır. Diğer bir ifadeyle öznellik üretimini hedefleyen kurumların kendisini dışarısından ayırmak için kullanmış oldukları sınırlar ortadan kalkmaktadır. Emperyal egemenlikle birlikte kurumsal duvarlar içerisinde 
işleyen mantık toplumsal alanın tümüne yayılmıştır. İçerisi ve dışarısı arasındaki ayrım ortadan kalkmıştır (Hardt ve Negri 2003a: 210). Mekansal bölünme üzerinde kurulu öznellik üretiminin krizi ve içerisi ve dışarısı ayrımına dayalı olmayan yeni öznellik biçimi aynı zamanda disiplin toplumundan kontrol toplumuna geçişi sembolize etmektedir. Sonuç olarak modern egemenlikten emperyal egemenliğe geçiş uzamsal sınırları ortadan kaldıran yeni bir iktidar mantığı üzerinden anlaşılabilir.

\section{Biopolitik Üretim Ya da Hayatın Üretimi}

İmparatorluk, çağdaş kapitalizmdeki bir dizi değişimin sonucunda ortaya çıkmıştır. Kapitalist üretim biçimindeki değişim ile birlikte ortaya yeni bir üretim örgütlenmesi oluşmuştur. Negri ve Hardt kapitalist üretimin yapısındaki bu değişimi biopolitik üretim kavramı etrafında çözümlemektedir. Biopolitik üretim, üretimin, nesnelerin üretiminden, hayatın ve öznelliğin üretimine dönüştüğüne ilişkin tarihsel eğilimi nitelemektedir. Birçok düşünür tarafından post-endüstriyel, post-fordist, bilgi ekonomisi kavramları etrafından tarif edilmeye çalışılan çağdaş ekonomik dönüşüm, Negri ve Hardt düşüncesinde maddi olmayan emeğin hakim olduğu biopolitik üretim olarak görülmektedir. Çağdaş İtalyan Otonomist düşüncesinin 1970’lerdeki çalışmaları da değer üretimin zamansal-mekansal ölçülemezliğinin yeni bir toplumsal durum ve ekonomik hayatın yeni bir örgütlenmesini ortaya çıkardığı üzerinedir. (Negri 2005b: 254). Fordizmin krizi olarak da bilinen üretim biçiminin dönüşümünde 1968 olayları ve işçi sınıfı mücadeleleri önemli bir yere sahiptir. Sınıf mücadelesi ve toplumsal değişim talepleri sermaye birikimini değişime zorlamıştır. Üretim sürecindeki değişimle birlikte maddi malların üretimine dayanan endüstriyel emeğin hakimiyeti azalmış, maddi olmayan emeğin etkinliği artmıştır. Negri ve Hardt, sonuçta ortaya maddi ve kalıcı bir mal çıkarmayan, yani bir hizmet, bir kültürel ürün, bilgi ya da iletişim gibi maddiolmayan malları üreten emeği "maddi-olmayan emek" olarak adlandırmaktadır (Hardt ve Negri 2003a: 303). Negri'ye göre (2005: 160), küresel emek piyasasına bakıldığında maddi olmayan emek niceliksel olarak küçük bir yere sahipse de hizmet üretimi, endüstriyel ve tarımsal üretim faaliyetlerini belirleyen ana üretim haline gelmektedir. 
Hizmet üretiminin hakim bir konuma gelmesi üretim sürecini enformatik hale getirdiği gibi emeğin niteliğini, üretkenliğini değişime zorlamaktadır (Hardt ve Negri 2003a: 293). Yeni ekonomide hakim olan maddi olmayan emeğin iki ayırıcı boyutu vardır. İlki, dilsel ve entelektüel, ikincisi duygulanımsaldır. Negri’nin de belirttiği gibi:

[M]addi olmayan emek, yani maddi olmayan ürünler -bilgi, enformasyon, iletişim, dilsel ya da duygusal ilişkiler- üreten emek ortaya çıkmıştır. Hizmet sektöründeki emek, entelektüel emek ve bilişsel emek-bunlar hepsi- maddi olmayan emeğe gönderme yapar, ama bu terimlerden hiçbiri maddi emeğin genelliğini aktaramaz. Bir ilk yaklaşım olarak, maddi olmayan emek, emeğin fiili uygulamalarıyla bütünleşen iki ana biçimde düşünülebilir. İlk biçim, her şeyden önce entelektüel ya da dilsel emeğe gönderme yapar: sözgelimi, problem çözmek, simgesel ve analitik işlemler ve dilsel anlatımlar geliştirmek... buna karşllık, öteki maddi olmayan emek biçimine "duygulanımsal emek" adını veriyoruz. Duygulanımlar, zihinsel olgu niteliği taşıyan duygulardan farklı olarak, zihni ve bedeni eşit ölçüde ilgilendirirler (2005a: 159-160).

Negri ve Hardt'ın biopolitik üretim kavramı Foucault tarafından geliştirilen bioiktidar kavramının yeni bir yorumlanmasına dayanmaktadır. Foucault'un iktidar yaklaşımı, disiplin pratiklerinin çeşitli mekansal aygıtlar aracılığıyla toplumsalın tamamını kuşatacak biçimde yaygınlaşmasını sağlayan kurumsal mimarinin çözümlenmesine dayanmaktadır (Hardt ve Negri 2011: 69). Bio-iktidar yaşam üzerindeki iktidardır. Negri ve Hardt'a göre biopolitik üretim, Foucaultcu anlamda bioiktidar kavramından farklı olarak yaşam üzerindeki iktidar olarak değil, direnmek ve alternatif öznellikler üretmek iç yaşam gücüne dayan bir modeldir (Hardt ve Negri 2011: 70). Negri ve Hardt'a göre biopolitik üretimin ile birlikte Foucault'un tarif ettiği disiplinci kurumlar yerini denetim ve kontrol aygitlarına bırakmaktadır. Disiplin toplumundan denetim toplumuna geçiş Negri ve Hardt'ın Deleuze ${ }^{3}$ okumasına dayanmaktadır. Buna göre disiplin toplumu, "toplumsal komuta mekanizmasının, (adetleri, alışkanlıkları ve üretici pratikleri üreten ve düzenleyen) yaygın bir dispositifler yada aygitlar şebekesi yoluyla kurulduğu toplum" olarak tarif edilirken, denetim toplumu "komuta (denetim) mekanizmalarının giderek daha fazla toplumsal alana içkin hale geldiği, yurttaşların beyinleri ve bedenleri üzerinden dağıtıldığı bir toplum"dur

\footnotetext{
${ }^{3}$ Bkz. (Deleuze 2001).
} 
(Hardt ve Negri 2003a: 47). Negri ve Hardt bu tarihsel değişimi bio-iktidardan biopolitik iktidara yönelik tarihsel bir değişim olarak görmektedir. Biopolitik üretim, üretimin herhangi bir mekansal-zamansal sınırlamaya tabi olmadığı, sadece maddi malların üretiminin değil aynı zamanda yaşamın üretiminin merkeze konulduğu bir üretim biçimidir. Üretimin, hayatın üretimi olarak şekillenmesi üretken emek ve üretken olmayan emek, kafa ve kol emeği arasındaki ayrımın bulanıklaşmasına neden olmaktadır (Lazzarato 2005: 228). Üretim sadece fabrika, büro, vb. alanlarda yapılan bir faaliyet olarak görülemez. Bu bağlamda sanayi toplumunun bir özelliği olan ekonomi ve siyaset arasındaki ayrım anlamını yitirdiği gibi değer üreten-değer üretmeyen mekanlar ayrımı da anlamını yitirmektedir. Dolayısıyla biopolitik üretimin açığa çıkan diğer bir yönü de, dilsel, kültürel, kentsel, siyasal, iletişimsel, duygulanımsal boyutlarıyla üretimin ortak paydanın üretimi haline gelmiş olmasıdır.

Negri ve Hardt'a göre biopolitik üretimin ortaya çıkışını olanaklı kılan üç eğilim vardır. Birincisi; hizmet üretimin baskın bir üretim biçimi haline gelmesi, ikincisi çalışmanın kadınsılaşması ve kadın emeğinin kapitalist üretim süreci içerisindeki niceliğinin artışı, Üçüncü olarak da emek piyasasının küresel göç dalgaları ile 1rksal olarak farklılaşmasıdır (Hardt ve Negri 2011: 141-144). Bu üç eğilim üretimin doğasında köklü değişimleri beraberinde getirmiştir. Bu dönüşümle birlikte 19. ve 20 . yüzyılda hakim bir üretim biçimi olan sanayi üretimi yerini hizmet üretimine bırakmaktadır. Bu geçiş maddi malların üretiminden daha çok maddi olmayan iletişim, enformasyon, duygulanım üreten emek biçimlerinin etkin olduğu malların üretimine doğru tarihsel bir değişimi ortaya çıkarmıştır (Hardt ve Negri 2011: 142). Hizmet üretiminin giderek enformasyonel-duygulanımsal hale gelmesi, reklamcılık, eğlence işleri, sağlık ve evde bakım, bilgisayar programcılığı, pazarlama gibi iş biçimlerinin artışına neden olmaktadır. $\mathrm{Bu}$ değişimi başka bir perspektiften tartışan Manuel Castells'e (2008: 281) göre de enformasyon toplumunda bilgisayar yazılımı, video üretimi, mikro-elektronik tasarımı, biyo-teknolojiye dayalı tarım gibi bir çok iş biçimi, maddi ile maddi olmayan malların nasıl tanımlanacağını taştırmaya açmakta ve bilgiyi toplumsal zenginliğin merkezine getirmektedir. Negri ve Hardt'a göre de bu süreç 
modern toplumda dikotomik bir şekilde ayrıştırılan kafa ve kol emeği arasındaki bölünmeleri ortadan kaldırmaktadır. Biopolitik üretimde “düşünsel ve duygulanımsal emek salt belirli organlara özgü değildir, aksine tüm beden ve zihni kapsar. Bir başka ifadeyle maddi olmayan üretimde, üretim edimi hem bedensel hem zihinseldir" (Hardt ve Negri 2011: 142). Çalışma hayatındaki ve çağdaş kapitalizmdeki dönüşümler “toplumsal olarak tanımlanabilen ve toplumsal bütünün üretim ve yeniden üretiminde norma bağlı, standart bir işlevi yerine getirme" biçimindeki çalışma anlayışını ortadan kaldırma eğilimindedir (Gorz 2001: 12). Küresel emek piyasası içerisinde esnek ve yarı zamanlı çalışma niceliksel olarak artmaktadır. Esnek emek piyasası kadın emeğine ihtiyaç duymaktadır. Bu sürecin ikili bir yönü vardır. Bir taraftan kadınların çalışma hayatına girmesi erkeğin hanenin geçimini sağladığı anlayışına dayanan ataerkil ilişkileri dönüştürmekte, diğer yandan hasta ve yaşlı bakımı, sağlık, eğitim, iletişim, taşımacılık gibi farklı sektörlerde duygulanımsal ve hissi emek biçiminin etkinlik kazanmasına neden olmaktadır. Bu bakımdan emek piyasasının "kadınsılaşması", duygulanımsal, iletişimsel emek biçimlerinin biopolitik üretimde baskın bir emek biçimi olmaya başladığını göstermektedir (Hardt ve Negri 2011: 142). Biopolitik üretimin önemli bir boyutu da küresel emek piyasasının çokkültürlü hale gelmiş olması oluşturmaktadır.

Üretimin biopolitikleşmesi, duygulanımsal, iletişimsel ve enformasyonel emek biçimlerinin nasıl denetleneceği sorusunu da beraberinde getirmektedir. Çünkü sermaye her zaman emeğin komuta ve kontrolüne ihtiyaç duyar. Negri ve Hardt'a göre emek ve sermaye arasındaki ayrıma dayanan sermayenin organik bileşimi yaklaşımı çağdaş kapitalizmdeki değişimlerde birlikte anlamını yitirmektedir. Biopolitik üretimde, üretimin ortak paydanın üretimine ve toplumun tamamının katılımına dayanan doğası sermayeyi üretim sürecine daha fazla dişsal hale getirmektedir. Başka bir değişle küresel finansal ağlar, telif, patent gibi yeni ortaya çıkan mülkiyet biçimleri sermayeyi üretim sürecinin dışında, toplumun zenginliğine el koyan bir ilişki olarak görmeyi zorunlu k1lmaktadır. Biopolitik üretimle birlikte, üretim sadece fabrika, büro vb. alanlarda gerçekleştirilen bir faaliyet olmaktan çıkmaktadır. Fabrika, emeğin fabrika 
duvarları içinde disipline edilmesini olanaklı kılmaktaydı. Fordizm bu zamansal ve mekansal denetimin en ileri yönetim tekniği olarak görülmekteydi. Buna karşın üretim belirli bir mekana bağlı olarak gerçekleştirilen bir faaliyet olmaktan çıktığında emek güçleri sermaye tarafından nasıl disipline edilecektir? Negri ve Hardt'a göre küresel borç ekonomisi ve borçlandırma süreçleri emeğin yeni denetin ve kontrol biçimlerini oluşturmaktadır (Hardt ve Negri 2012: 20). Bu bakımdan eğer eğitim, sağlık, konut borçlarınız varsa çalışmayı tercih etmek dışında başka bir alternatifiniz yoktur. Sermayenin emeği disipline edecek mekansal sınırlardan yoksun hale gelmiş olması, yeni kontrol düzeneklerini beraberinde getirir. Negri ve Hardt'a göre biopolitik üretimin biçiminin denetim pratikleri üçlü bir yöne sahiptir. İlk olarak, ortak paydaya el koyulmasıdır. Biopolitik üretim maddi bir malın üretimine dayanmadığından, bilgiler, simgeler, semboller, duygular ve enformasyonlar ancak toplumun tamaminın katılımıyla üretilebilen ve bir kişinin mülkü olamayacak kadar geniş bir ortaklığı niteler. İkinci olarak da, emeğin "kadınsılaşması"yla esnek, yarı zamanlı ve güvencesiz çalışmanın istisnai olmaktan daha çok kural haline gelmiş olmasıdır. Güvencesizlik, çalışanların daha fazla çalışmaya razı olmasını sağlar. Üçüncü olarak, küresel ölçekte emek ve göçün akışkanlığını önleyen fiziksel ve toplumsal sınırların varlığı yeni denetim stratejinin bir parçasıdır (Hardt ve Negri 2011: 156). Başka bir değişle küresel emek hareketliliği önündeki bariyerler emek gücünün ulusal sınırlara hapsedilmesini olanaklı kılmaktadır.

\section{Yeni Bir Öznellik Biçimi Olarak Çokluk}

İmparatorluk kitabının devamı niteliğindeki Çokluk: Imparatorluk Çă̆ında Savaş ve Demokrasi adlı kitap yeni egemenlik biçimine karşı alternatif toplumsal hareketlerin ve tarihsel özne olarak çokluk örgütlenmesinin ana hatlarını tartışmaya açmaktadır. İmparatorluk metni genel itibariyle siyasal ve ekonomik dönüşümleri merkeze alan, yeni egemenlik biçimin geometrisini çıkarma hedefini taşırken, Çokluk çalışması emperyal egemenlik çağında çokluğun soykütügünü merkeze koymaktadır. Negri ve Hardt çokluğu imparatorluğa karşı örgütlenen tekilliklerin yatay ve hiyerarşiye 
dayanmayan demokratik bir örgütlenmesi olarak görmektedir. Buna karşın imparatorluk komuta ve kontrolü merkeze alan hiyerarşiler ve esnek örgütlenmeler yoluyla sürdürülen ağ yapısı ortaya çıkarmıştır. İmparatorluğun ă̆ şeklinde örgütlenen hiyerarşik iktidar düzeneklerine karşıt bir konumda yer alan çokluk ise tekilliklerin yatay örgütlenmesini merkeze alan bir model uyarınca hareket etmektedir (Hardt ve Negri 2004 12). Bu yönüyle çokluk, imparatorluğa karşı olan farklı toplumsal kimlikleri bir araya getirmeyi amaçlayan bir ağ mantığı olarak tanımlanmaktadır. Çokluk, ağs1 yapısı uyarınca bir birinden bağımsız ve otonom bir yöne sahip farklı tekillikleri içermekle birlikte, aynı zamanda kendini siyasal proje ve kolektif direniş aygıtı olarak örgütleme potansiyeline sahiptir.

Çokluk kavramı, halk, kitle, avam ve işçi sınıfı gibi tek bir kimliğe ve özne anlayışına dayanmayan, buna karşın ortak paydanın üretimini merkeze alan tekilliklerin demokratik birlikteliğidir. İlk olarak, birçok farklı siyasal projenin öznesi olarak görülen halk kavramı, içsel farklılıkların tek bir siyasal kimlik etrafinda örgütlendiği ve tek bir potada eritildiği bütüncül bir kimlik olarak tanımlanmalıdır. Fransız devriminden, çeşitli halk hareketlerine ve popülist iktidarlara kadar bütün siyasal tahayyüller halkı tekin ve birin kolektif örgütlenmesi olarak görmektedir. Halk, homojen bir nüfus ve birlik olarak görülür. Negri’ye göre modern düşünce içerisinde Hobbes, Rousseau ve Hegel gibi figürler ancak halkın yönetebileceğini, çokluğun savaş ve kaosla eşdeğer olduğunu savunmuşlardır (Negri 2010: 15). İkinci olarak kitle ve avam, doğaları gereği farksızlık üzerine inşa edilmişlerdir. Kitle ve avam terimleri "kolayca manipüle edilebilme özellikleri nedeniyle tehlikeli ve şiddetli olan irrasyonel ve pasif” topluluğu tanımlar (Negri 2010: 17; Hardt ve Negri 2004: 113-114). Üçüncü olarak işçi sınıfı kavramı da, kapitalizmi yok edecek özne olarak sadece endüstriyel emeği merkeze alan özcü ve indirgemeci bir kavramdır. İşçi sınıf kavramı, üretken-üretken olmayan emek, lümpen proletarya, ev içi- ev dışı emek gibi karşıtlıkları üretir. Fabrika işçisi haricindeki yoksul, işsiz, lümpen proletaryayı ve ücretlendirilmemiş ev içi emeği işçi sınıfı tanımının dışında ele alır. Ayrıca tarım ve hizmet işçilerini işçi sınıfının müttefik kuvvetleri olarak tanımlar. Bu açıdan endüstriyel emek diğer emek biçimlerini içerisinde örgütleyen özcü 
ve teke indirgeyen bir özne olarak tarif edilir. Buna karşın çokluk, temsilin reddi, ölçülemez çeşitlilik olarak görülür (Negri 2010: 17).

Negri ve Hardt'a göre çokluk, yukarıda tanımladığımız bu kavramlardan farklıdır. $\mathrm{Bu}$ yönüyle işçi sınıfı gibi sadece ekonomik bir kategori değildir. Bunun yanında kültürel, ırksal ve cinsiyet ile tanımlanan tüm özne biçimlerini içerisinde barındırır. Çokluk, bütün öznelerin demokratik farklılıklarını kabul eden, bu yönüyle iç farklılıkları olan ve ortak paydaya dayanan bir ağ mantığıdır (Hardt ve Negri 2004: 12). $\mathrm{Bu}$ ağ modern siyaset anlayışının tek bir egemen otoriteye dayalı, hiyerarşik ve dikey örgütlenme mantığından farklı olarak yatay ve çoğul bir yöne sahiptir. Bu açıdan çokluk “öznelerin kendi adlarına konuşmalarını gerektiren ve bireysel iyelik yerine, temsil edilemeyen tekilliklerle" ilişkili bir içkinliğin adıdır (Negri 2010: 16). Negri ve Hardt'ın da belirttiği gibi "siyaset felsefesinin sürekli tekrar edilen doğrularından biri sadece bir'in yönetebileceğidir. Bu bir monark, parti, halk ya da birey olabilir. Üniter olmayan ve çoğul kalan toplumsal öznelerse yönetemez, onların yönetilmeleri gerekir. Dolayısıyla her egemen iktidar, zorunlu olarak, komuta veren bir baştan, itaat eden uzuvlardan ve yöneticiyi destekleyen organlardan oluşan bir siyasal bedendir. Çokluk kavramıysa, egemenlik konusundaki bu yerleşik doğruya meydan okur. Çokluk her ne kadar çoğul kalsa ve farklar barındırsa da, ortak hareket etme ve kendini yönetme yetisine sahiptir. İçinde komuta eden ve itaat eden parçaların olduğu bir siyasal beden değil, kendi kendini yöneten bir canlı ettir” (2004: 114).

Negri ve Hardt'a göre (2004: 117) çokluk aynı zamanda bir sınıf kavramıdır. Çokluk, biopolitik üretim çağında, küresel komuta ve denetim rejimine direniş gösteren ve bu yönüyle ortak paydanın üretimini gerçekleştiren öznedir. Fabrika, maddi malların üretimi üzerine temellendiğinden hakim olan emek biçimi endüstriyel emektir. Fabrika, disiplinci yapı ve kurumların mantığı uyarınca işleyen ve değerin üretildiği mekansal yapıdır. Çağdaş kapitalizmde ise değer üretimi toplumsal bünyenin tamamına yayılmış, biopolitik bir hal almıştır. Üretim sadece ekonomik değer üretimi değil kültürel ve toplumsal bünyenin bir bütün olarak üretimi haline gelmiştir. Biopolitik üretimde, üretim mantığı daha fazla iletişimsel, duygulanımsal, simgesel ve enformasyonel hale 
geldiğinden, üretim ortak paydanın ve müştereklerin üretimi haline gelmektedir. Biopolitik üretimde sömürü, çokluğun ürettiği ortak paydanın ele geçirilmesidir. Negri ve Hardt, biopolitik üretim ve ortak payda konusunda doğal ortak varoluş ve yapay ortak varoluş ayrımına gidilmesi gerektiğini vurgulamaktadırlar. Doğal ortak varoluş, hava, toprak, su, doğalgaz gibi insanlığın ortak mülklerine gönderme yaparken, yapay ortak varoluş ise günümüz biopolitik üretimin doğası gereği simgelerin, sembollerin, enformasyonun ve duyguların ortak bir varoluş çerçevesinde üretilmesine gönderme yapmaktadır (Hardt ve Negri 2011: 149). Bu yönüyle üretim hayatın üretimi olarak tanımlandığında, sermaye üretim sürecine dişsal hale gelmektedir (Hardt ve Negri 2011: 146-147). Sermaye artık sadece üretim sürecinin sonucunda emeğin ürünlerine kar yoluyla el koymamakta, aynı zamanda telif, patent veya kentsel alanlar vb. gibi ortak paydaya dayanan zenginliğe rant mekanizmaları yoluyla el koymaktadır. Müşterek olana ve ortak paydaya el koyma süreci, çokluğunun sınıfsal yönüne işaret eder. Çokluk bu açıdan zenginliğin üretiminin ortak payda etrafında örgütlendiği dünyamızda farklılıkları yok saymayan ve tek bir özne üzerinden değerlendiremeyecek kadar geniş bir sınıf kategorisi olarak anlaşılmalıdır. Elbette bu sınıf kavramı ekonomik kategorilerle anlaşılabilecek toplumsal bir özne değildir. Sınıf kavramı iktidara karşıtlığı ölçüsünde sınıf mücadelesi tarafından belirlenir. Bu sınıf aynı zamanda "siyasal bir proje" önerme potansiyelini taşır. Çokluk, diğer sınıf kavramları gibi sermayenin idaresinde çalışan ve onu reddeden herkesi kapsayan bir şemsiyedir.

Sınıf, sınıf mücadelesi tarafından belirlenir. Elbette, insanlar birçok farklı şekilde sınıflara ayrılabilir (saç rengi, kan grubu vs.), ama asıl önemli olan sınıflar, kolektif mücadele hatlarında tanımlanan sinıflardır. Bu bakımdan, ırk da ekonomik sınıf kadar siyasal bir kavramdır. Irkı belirleyen, etnik grup ya da deri rengi değildir; ırk siyasal biçimde, kolektif mücadeleyle belirlenir. Örneğin Jean Paul Sartre'ın, Yahudi'yi Yahudi karşıtlı̆̆ 1 yaratır, iddiasındaki gibi, kimileri ırkın ırksal baskı tarafından yaratıldığını savunur. Bu mantık bir adım öteye taşınmalıdır: Irk, ırksal baskı karşısındaki kolektif direnişten doğar. Ekonomik sınıf da, aynı biçimde kolektif direniş eylemleriyle oluşur. Dolayısıyla ekonomik sınıfın analizi de, ırkın analizi gibi, ampirik farkları kataloglamakla değil iktidara kolektif direniş hatlarını incelemekle başlamalıdır. Kısacası, sınıf siyasal bir kavramdır, zira sınıf ortak mücadele eden bir kolektiviteden başka bir şey olamaz" (Hardt ve Negri 2004: 118). 
$\mathrm{Bu}$ şekilde kapitalizm, emek ve sermaye gibi iki antagonistik sınıfın mücadelesi olarak okunmaktadır. Sanayi devrimi sonrası bütün Avrupa boyunca işçi sınıfı niceliksel olarak değil, niteliksel anlamda diğer emek biçimleri içerisinde hakim bir konuma gelmiştir. Sınıf hareketleri birçok ülkede toplumsal hareketlerin temelini oluşturmuştur. Günümüzde ise 19. yüzyıldakinden farklı olarak kapitalist üretim biçimindeki değişimler yeni özne biçimlerini ortaya çıkarmıştır. Negri ve Hardt’a göre biopolitik üretimin hakim olduğu günümüzde üretim iletişimsel, enformasyonel, duygulanımsal emek biçimleri tarafından tanımlanmaktadır. Küresel ölçekte maddi olmayan emek tarımsal ve endüstriyel emek içerisindeki niteliksel yoğunluğunu arttırmaktadır. Biopolitik üretim bu açıdan bir emek biçiminin diğer emek biçimleri üzerindeki baskın olma biçimini olanaksız kılmıştır. Çokluk da biopolitik üretimin öznesi olarak farklı sınıfları, kimlikleri, etnik ve kültürel hareketleri ortak bir siyasal organizasyon içinde örgütlemektedir. Çokluk, bu haliyle küresel komuta ve kontrol yapılarını reddeden, işbirliğini ve ortak olanın kurumlarını inşa edecek tekillikleri bünyesinde barındıran karşı-iktidardır. Çokluk, faşizme karşı direnişlerden fabrika grevlerine, savaş karşıtı hareketten kadın mücadelelerine ve çevreci hareketlere kadar farklı mücadele alanlarını ortak bir ağ içinde buluşturan öznelliktir. Çokluk, Ortodoks Marxist siyaset anlayışının tek bir özne fikrine ve devlet iktidarının ele geçirilmesini hedefleyen devrim stratejine karşıt bir biçimde, demokrasiyi farklılıkların birliği ve iktidarı gündelik hayat içindeki ilişkiler kümesi olarak ele alan yeni bir siyaset tarzını gündeme getirmektedir. Çokluk’un böylesi bir tanımı modern örgütsel kurumları ve özellikle katı, hiyerarşik bir örgütlenme olan parti modelini dışarda bırakmayı zorunlu kılar. Çokluk bu açıdan iletişimsel, enformasyonel ve duygulanımsal ortaklıkları nedeniyle yatay ve merkezsiz örgütlenmeler yoluyla tanımlanmalıdır (Hardt ve Negri 2011: 173). Çokluk, 19. yüzyılın işçi sınıfın yerine geçen, biopolitik üretimin öznesi ve imparatorluğun komuta ve kontrolüne karşı bir direniş makinesi olarak tarif edilmektedir. 


\section{Sonuç}

İmparatorluk, çokluk ve biopolitik üretim kavramları çağdaş dünyanın değişim dinamiklerini anlama konusunda önemli bir tartışma zemini yaratmıştır. İmparatorluk tartışması modern egemenlik mantığı içerisinde üretilmiş olan içerisi-dışarısı, yerelküresel, siyah-beyaz gibi dikotomik bölünmelerin yeni ortaya çıkmakta olan egemenlik biçimlerini anlama konusunda ne denli yetersiz olduğunu tartışmaya açmaktadır. İmparatorluk tartışması yeni bir egemenlik biçiminin doğuşuna ve yeni bir küresel düzenin kuruluşuna gönderme yapmaktadır. Özellikle, Sovyetler Birliği’nin yıkılması tek bir ideolojik perspektife sahip yeni bir dünyanın oluşumu olarak sıkça tartış1lmıştır. Tek kutuplu dünya ve tarihin sonu tartışmaları ortaya çıkmakta olan küresel egemenlik mantığının tanımlanmasına yöneliktir. İmparatorluk söylemi küreselleşme sürecinin neden olduğu ulus-devlet egemenliğindeki gerilemeye gönderme yapar. Ulus-devletler egemen otoriteler olarak emek, sermaye ve metaların dolaşımı üzerindeki kontrol olanaklarını yitirmektedir. Buna neden olan süreç iletişim ve ulaşım olanaklarının artışı, finansal ağların bütünleşmesi vb. süreçlerin küresel bir düzenin oluşumuna neden olan maddi dünyadaki değişimlerdir. Bu bağlamda küresel bir egemenlik mantığı ortaya çıkmaktadır. İmparatorluk egemenliğin merkezsizliği üzerinden tartışılmaktadır. Küresel düzen bir ağ olarak görülmektedir. Elbette burada vurgulamak gerekir ki "ağ modeli" sanki ağa dahil olan bütün devletlerin, bölgelerin veya kentlerin eşitliği üzerine temelleniyormuş gibi görülmemelidir. İmparatorluk tam da küreselleşme sürecinin yarattığı eşitsizlik ve savaş halini yönetmeye aday bir egemenlik olarak görülmektedir. Bu açıdan küresel bir yönetimsellik mantığı olarak görülmelidir.

Çokluk fikri modern temsili demokratik yapıların ve öznellik tartışmalarının merkezi kavramlarından biri haline gelmiştir. Çokluk bu yönüyle küresel imparatorluğun komuta ve kontrol yapılarına karşı çıkan direniş-makinesi olarak görülmektedir. Özellikle çokluk kavramı üzerine yapılan tartışmalar ve son dönemdeki toplumsal hareketlerin politika yapma biçimlerindeki değişim, çokluk fikrinin politik bir öznellik olarak görünür hale geldiği şeklinde yorumlanmaktadır. 1999 Seattle ve Cenova'daki küreselleşme karşıtı gösterilerden, Tahrir, Zuccoti Park, Placa Catalunya, 
Puerto del Sol ve Syntagma gibi kentsel mekanı işgal hareketlerine kadar farklı tarihsel dönemlerdeki toplumsal hareketlerin çokluk fikriyle ilişkisi çağdaş sosyal bilimler çalışmalarında tartışılmaya başlanmıştır. Çokluk bu tartışmalarda ortak payda etrafinda örgütlenen ve temsili siyasetin sınırlarını aşan parti, sendika gibi kurumsal siyasetin dışında, siyaset yapmanın yeni biçimlerini üreten tarihsel özne olarak görülmektedir. Kentsel mekanın ortak bir alan olarak görülmesi, merkezi otoritenin ve dikey siyasal organizasyonların reddi çokluğun kolektif doğasının bir ürünü olarak yeni bir demokratik ufuk olarak görülmektedir.

Biopolitik üretim tartışması ise çağdaş kapitalizmdeki çalışma ve iş örüntülerinin değişimini merkeze koyan bir tartışmayı gündeme getirmektedir. Özellikle 1970’lerden itibaren kapitalizmin girmiş olduğu krizleri aşmaya yönelik tutumu emek bileşiminin değişimine neden olmuştur. Üretim git gide maddi malların üretiminden maddi olmayan simgelerin, sembollerin, imajların, iletişimin üretimine doğru ilerlemektedir. Maddi olmayan üretimin önemli bir yönü iletişimsel ve duygulanımsal emek biçimlerinin ortaya çıkmış olmasıdır. Bu yönüyle üretim genel olarak ortak olanların üretimine dayanmaktadır. $\mathrm{Bu}$ üretim süreci içerisinde sermaye ise üretime maddi malların üretiminde olduğu gibi kar biçiminde değil, dışsal olarak rant mekanizmaları yoluyla el koymaktadır. Özellikle telif ve patent yasalarla bilgi gibi maddi olmayan zenginliğin çitlenmesi durumu söz konusu iken, artan kentsel rantlar yoluyla toprakta rant mekanizmalarının önemli bir görünüm sergilediği ortadadır. Bu sürecin önemli bir yönünü küresel piyasaların ve çokuluslu şirketlerin finansal ağlarla bir birine bağlanması süreci de vardır. Finansallaşma ve gündelik hayatın finansallaşması, ortak zenginliğin rant mekanizmaları yoluyla el konulmasının önemli bir boyutu halini almıştır. Toparlamak gerekirse üretim maddi malların üretiminden maddi olmayan emeğin hakim bir özellik kazandığı hayatın üretimine dönüştükçe, üretimin öznelliklerin üretimi biçimini almaktadır.

Sonuç olarak Negri ve Hardt düşüncesinde merkezi bir yere sahip olan İmparatorluk, Çokluk ve biopolitik üretim kavramları çağdaş kapitalizmde meydana gelen değişimleri anlama ve değişime uygun siyasal bir teori oluşturma çabası olarak 
okunabilir. Çağdaş kapitalizmin imparatorluk biçiminde örgütlemesine neden olan süreçlerin ve değişmekte olan siyasal egemenlik yapılarının bir tür yeni ekonomik düzene içkin olduğunu söylemek yanlış olmaz. Bu ekonomik düzen zenginliğin üretimini maddi olmayan malların üretimi biçiminde örgütlediği ölçüde -biopolitik bir hal aldıkça- iktidarda yaşam üzerindeki iktidar olmaktan daha çok yaşamın kendisini üreten bir yapıya bürünmektedir. Çokluk fikri bu yönüyle yeni iktidar yapılarına karşı örgütlenen bir öznellik biçimi olarak karşımıza çıkmaktadır. 


\section{KAYNAKÇA}

CASTELLS, Manuel (2008). Enformasyon Çă̆l: Ekonomi, Toplum ve Kültür. Birinci Cilt. A $\breve{g}$ Toplumunun Yükselişi, çev. Ebru Kılınç, İstanbul: Bilgi Üniversitesi Yayınları.

CASTELLS, Manuel (2015). Kent, Sınıf, İktidar, çev. Asuman Türkün, Ankara: Phoneix Yayınları.

DELEUZE, Gilles (2001). "Denetim Toplumları Konusunda Bir Ek", çev. Ulus Baker, Birikim Dergisi, 142-143: 23-26.

FOUCAULT, Michel (2006). Hapishanenin Doğuşu, çev. Mehmet Ali Kılıçbay, Ankara: İmge Yayınları.

FOUCAULT, Michel (2010). Cinselliğin Tarihi, çev. H. Uğur Tanrı̈ver, İstanbul: Ayrıntı Yayınları.

FRISBY, David (2012). Modernlik Fragmanları, çev. Akın Terzi, İstanbul: Metis Yayınları.

GILBERT, Jeremy (2012). Antikapitalizm ve Kültür, çev. Tuğba Sağlam, İstanbul: Ayrıntı Yayınları. Yayınlar1.

GORZ, Andre (2001). Yaşadığımız Sefalet, çev. Nilgün Tutal, İstanbul: Ayrıntı

HARDT, Michael ve Antonio NEGRİ (2003a). Imparatorluk, çev. Abdullah Y1lmaz, İstanbul: Ayrıntı Yayınları.

HARDT, Michael ve Antonio NEGRİ (2003b). Dionysos'un Emeği Devlet Biçiminin bir Eleştirisi, Çev. Ertuğrul Başer, İstanbul: İletişim Yayınları.

HARDT, Michael ve Antonio NEGRİ (2004). Çokluk: Imparatorluk Çağında Savaş ve Demokrasi, çev. Barış Yıldırım, İstanbul: Ayrıntı yayınları.

HARDT, Michael ve Antonio NEGRİ (2011). Ortak Zenginlik, çev. E. Barış Y1ldırım, İstanbul: Ayrıntı Yayınları.

HARDT, Michael ve NEGRİ, Antonio (2012). Duyuru, çev. Abdullah Yılmaz, İstanbul: Ayrıntı Yayınları.

LACLAU, Ernesto (2007). Popülist Akıl Üzerine, çev. N. Betül Çelik, İstanbul: Epos Yayınları.

LACLAU, Ernesto ve Mouffe, Chantal (2008). Hegemonya ve Sosyalist Strateji: Radikal Demokratik Bir Politikaya Doğru, çev. Ahmet Kardam, İstanbul: İletişim Yayınları. 
Aykut AYKUTALP \& Adem ÇELİK, “Antonio Negri ve Michael Hardt Düşüncesinde İmparatorluk, Çokluk ve Biopolitik Üretim Kavramları Üzerine,” Kaygı, 31/2018: 404-430.

LAZZARATO, Maurizio (2005). "Maddi Olmayan Emek", İtalya'da Kurucu Düşünce ve Kurucu Politika, çev. Selen Göbelez \& Sinem Özer, ss. 227- 246, İstanbul: Otonom Yayıncilik.

LEMKE, Thomas (2013). Biyopolitika, çev. Utku Özmakas, İstanbul: İletişim Yayınları.

LUXEMBURG, Rosa (2004). Sermaye Birikimi, çev. Tayfun Ertan, İstanbul: Belge Yayınları.

MAY, Todd (2000). Postyapısalcı Anarşizmin Siyaset Felsefesi, çev. Rahmi Öğdül, İstanbul Ayrıntı Yayınları.

NEGRI, Antonio (2005a). Imparatorluktaki Hareketler, çev. Kemal Atakay, İstanbul: Otonom Yayınc1lık.

NEGRI, Antonio (2005b). "Marx Üzerine Yirmi Tez: Bugünkü Sinıf Durumunun Yorumu", Marksizmin Ötesinde Marksizm, derl. S. Makdisi, C. Casarino, \& R. E. Karl, çev. Aynur Özuğurlu, ss. 249-294, Ankara: İmge Yayınları.

NEGRI, Antonio (2010). "Çokluk Eleştirilerinin Eleştirisi”, Çev. Serkan Akbaş, Dipnot Sosyal Bilimler Dergisi, Say1: 3, ss. 16-24.

NEWMAN, Saul (2006). Bakunin'den Lacan'a: Anti-Otoriteryanizm ve İktidarın Altüst Oluşu, Çev. Kurşat Kızıltuğ, İstanbul: Ayrıntı Yayınları. Yayınları.

POLANYI, Karl (2006). Büyük Dönüşüm, çev. Ayşe Buğra, İstanbul: İletişim

WEBER, Max (1993). Sosyoloji Yazıları, çev. Taha Parla, İstanbul: Hürriyet Vakfı Yayınları. 